Volume 4 No 1 September 2018 p-ISSN : 2460-8750 e-ISSN : 2615-1731

http://dx.doi.org/10.26858/talenta.v4i1.6525

\title{
HUBUNGAN PERSEPSI MAHASISWA TERHADAP PEMBELAJARAN REFLEKTIF DENGAN HASIL BELAJAR PADA MAHASISWA PSIKOLOGI FAKULTAS KEDOKTERAN UNHAS
}

\author{
Wahid Hasyim ${ }^{1}$, Nurul Aisyah ${ }^{2}$, Jauri Rakasiwi ${ }^{3}$, Umniyah Saleh ${ }^{4}$ \\ 1,2,3,4 Prodi Psikologi Fakultas Kedokteran Universitas Hasanuddin. Indonesia \\ Email: ${ }^{1}$ Wahidcreate@ @otmail.com, ${ }^{2}$ Neah0111@gmail.com, ${ }^{3}$ Jauri.rakasiwi@gmail.com, \\ ${ }^{4}$ unee_saleh@yahoo.com
}

(C2018 -JPT Fakultas Psikologi Universitas Negeri Makassar. Ini adalah artikel dengan akses terbuka dibawah licenci CC BY-NC-4.0 (https://creativecommons.org/licenses/by-nc/4.0/ ).

\begin{abstract}
Abstrack. This research aimed to determine whether there is a relationship between perception of reflective learning and learning outcome of student of Psychology Program of Hasanuddin University. The data were collected trough a perception of reflective learning in form of a likert scale that was developed based on the concept of perception and reflective learning. Outcome learning is reviewed based on grade point average (GPA) of the sample. Research sample consisted of 103 student of Psychology Program of Hasanuddin University. The Data were analyzed by using Product Moment Correlation with SPSS 21 for windows. The Result showed significant value of 0.010 which smaller than 0.05 or $0.010<0.05$ which indicate that there is positice relation between student perceptions of reflective learning with Grade Point Average (GPA) in Psychology Program of Hasanuddin University. Pearson Correlation value in this study is 0254 , which means the relationship between the two variables is strong enough based on the criteria of relationship strength.
\end{abstract}

Keywords: student perception, reflective learning, Grade Point Average (GPA)

Abstrak. Penelitian ini bertujuan untuk mengetahui apakah ada hubungan persepsi terhadap pembelajaran reflektif dengan hasil belajar mahasiswa Prodi Psikologi Universitas Hasanuddin. Alat ukur yang digunakan untuk mengukur persepsi terhadap pembelajaran reflektif berupa skala likert yang dikembangkan berdasarkan konsep persepsi dan pembelajaran reflektif. Hasil belajar mahasiswa ditinjau berdasarkan Indeks prestasi Kumulatif (IPK) sampel. Sampel penelitian ini adalah 103 mahasiswa Psikologi Universitas Hasanuddin dengan 49 angkatan 2012 dan 54 angkatan 2013. Kemudian dengan bantuan SPSS versi 21, data diolah menggunakan korelasi Product Moment. Dari hasil pengujian menggunakan korelasi Product Moment menunjukkan nilai signifikansi 0.010 yang berarti lebih kecil dari 0.05 atau 0.010 $<0.05$ yang menunjukkan bahwa ada hubungan positif antara persepsi mahasiswa terhadap pembelajaran reflektif dengan hasil belajar (IPK) mahasiswa pada Program Studi Psikologi Fakultas Kedokteran Universitas Hasanuddin. Nilai Pearson Correlation pada penelitian ini adalah 0.254 yang berarti hubungan diantara kedua variable cukup kuat berdasarkan kriteria kekuatan hubunga.

Kata kunci: persepsi mahasiswa, pembelajaran reflektif, hasil belajar 


\section{PENDAHULUAN}

Proses pembelajaran merupakan salah satu unsur yang terpenting dalam mencapai keberhasilan dalam keseluruhan proses pendidikan. Slameto (2010) menjelaskan bahwa belajar merupakan proses usaha yang dilakukan untuk memperoleh suatu perubahan tingkah laku yang baru secara keseluruhan, sebagai hasil pengalaman interaksi dengan lingkungan.

Peningkatan mutu pendidikan dan pengembangan proses pembelajaran merupakan bagian yang menarik untuk dikaji. Perbedaan tingkat serap masingmasing individu terhadap materi yang dibawakan oleh fasilitator, menuntut fasilitator menggunakan inovasi-inovasi dalam metode pembelajaran sehingga memudahkan mahasiswa dalam memahami materi pembelajaran. Proses pembelajaran akan lebih bermakna ketika mahasiswa dapat menghubungkan materi pembelajaran dengan pengalaman sehari-hari. Dalam prinsip konstruktivisme, belajar bukan sekedar menghafal namun lebih dari itu, mahasiswa dapat mengkonstruksi pengetahuan melalui pengalamannya dan memberikan peluang untuk membangun pengetahuan dan pemahaman mengenai materi yang disampaikan. Model pembelajaran tersebut adalah model pembelajaran reflektif yang menjadi salah satu model pembelajaran yang terus berkembang dan banyak digunakan saat ini (Santrock, 2004).

Model pembelajaran reflektif yang dilakukan tergantung dari persepsi individu yang mengikuti proses pembelajaran. Persepsi merupakan proses menginterpretasi informasi yang diperoleh (Suharnan, 2005). Apabila individu yang mengikuti pembelajaran tersebut memiliki persepsi yang positif terhadap model pembelajaran yang diikuti, maka hasil yang didapatkan akan optimal. Hal ini sejalan dengan penelitian yang dilakukan oleh Mudayati (2008) yang menjelaskan bahwa persepsi positif tentang metode pembelajaran akan berpengaruh terhadap hasil belajar. Hasil suatu pembelajaran (kemampuan, keterampilan, dan sikap) dapat terwujud jika pembelajaran (kegiatan belajar mengajar) terjadi (Winkel, 2007)

Model pembelajaran reflektif saat ini sudah banyak digunakan di luar negeri dan merupakan model pembelajaran yang efektif bagi mahasiswa (Coughlan, 2007). Sedangkan untuk di Indonesia, model pembelajaran reflektif masih sangat kurang digunakan (Purba, 2013). Hal ini terjadi karena para pendidik lama masih percaya bahwa pendidik harus mengarahkan dan mengontrol cara belajar mahasiswa (Santrock, 2004). Metode pembelajaran 
yang masih dominan saat ini terpusat kepada pendidik, salah satu indikatornya yaitu pembelajaran masih dominan menggunakan metode ceramah dan mahasiswa yang lebih banyak pasif, sebagai pendengar di kelas. Mudayanti (2008) mengemukakan penggunaan metode tersebut membuat mahasiswa menjadi malas dan bosan terutama pada saat pertanyaan yang diajukan oleh mahasiswa tidak dijawab oleh pendidik.

Hasil survei awal peneliti yang dilakukan pada tanggal 16 Mei 2014 terhadap 6 orang mahasiswa di Program Studi Psikologi Fakultas Kedokteran Universitas Hasanuddin (UNHAS) yang terdiri dari 3 orang laki-laki dan 3 orang perempuan menyatakan bahwa metode pembelajaran reflektif itu sangat efektif digunakan karena dapat membantu mereka dalam mengoptimalkan pengetahuan yang mereka dapatkan di kelas pada saat dikelas mereka memperoleh materi dan setelah memperoleh materi tersebut mereka merefleksikannya sehingga apa yang disampaikan pada hari pembelajaran tersebut dapat dipahami dan diingat. Dikatakan pula bahwa dengan metode tersebut mereka dapat memahami materi pelajaran dan pada saat ujian mereka dapat menjawab dengan lancar berdasarkan refleksinya selama perkuliahan.

Terdapat penelitian sebelumnya mengenai pembelajaran reflektif. Salah satunya penelitian oleh Purba (2013) yang menggunakan metode eksperimen, menunjukkan bahwa ada pengaruh positif pemberian model pembelajaran reflektif yang diberikan kepada siswa. Nilai rata-rata siswa yang diberikan perlakuan (menggunakan model pembelajaran reflektif) lebih tinggi dibandingkan dengan sebelum mendapat perlakukan (tanpa menggunakan model pembelajaran reflektif).

Berdasarkan urairan tersebut, peneliti tertarik untuk mengetahui bagaimana hubungan antara persepsi mahasiswa terhadap pembelajaran reflektif dengan hasil belajar pada mahasiswa Psikologi Fakultas Kedokteran UNHAS.

\section{METODE}

Tipe penelitian yang dilakukan disini termasuk dalam penelitian kuantitatif dengan tipe korelasional, yaitu penelitian yang dilakukan untuk melihat hubungan diantara variabel (Azwar, 2011). Variabel independen dalam penelitian ini adalah persepsi mahasiswa terhadap pembelajaran reflektif. Sedangkan, variabel dependen adalah hasil belajar mahasiswa.

Definisi operasional persepsi terhadap pembelajaran reflektif merupakan pemaknaan atau penginterpretasian mahasiswa terhadap penerapan metode 
pembelajaran reflektif yang diukur menggunakan skala persepsi terhadap pembelajaran reflektif. Disisi lain, definisi operasional untuk variabel hasil belajar adalah hasil penilaian atau prestasi akademik mahasiswa yang telah mengikuti perkuliahan dengan sistem pembelajaran reflektif. Dimana hasil belajar mahasiswa dapat dilihat dari Indeks Prestasi Kumulatif (IPK) mahasiswa.

Penelitian ini dilaksanakan di Program Studi Psikologi Fakultas Kedokteran UNHAS pada Desember 2014 dengan mengambil populasi program studi psikologi sebanyak 103 yang terdiri dari angkatan 2012 dan 2013, 49 mahasiswa angkatan 2012 dan 54 mahasiswa angkatan 2013. Pengambilan data menggunakan skala. Skala merupakan teknik pengumpulan data yang bersifat mengukur, karena diperoleh hasil ukur yang berbentuk angka-angka (Sukmadinata, 2007). Skala yang digunakan dalam penelitian ini adalah skala likert.

Penganalisisan data merupakan proses lanjutan dari proses pengolahan data untuk melihat bagaimana menginterpretasikan data, kemudian menganalisis data dari hasil yang sudah ada. Penganalisisan data bertujuan agar data dapat dibaca dan ditafsirkan (Azwar, 2011). Setelah semua data terkumpul dilanjutkan analisis data dengan menggunakan bantuan computer program SPSS for windows versi 21, yaitu korelasi Product Moment dari Pearson. Teknik korelasi ini digunakan untuk mencari hubungan dua variabel.

\section{HASIL DAN PEMBAHASAN}

Hasil

Hasil yang diperoleh pada penelitian ini berupa skor skala persepsi mahasiswa terhadap pembelajar reflektif, nilai hasil belajar (IPK), dan hubungan antara persepsi mahasiswa terhadap pembelajar reflektif dengan hasil belajar. Hasil penelitian tersebut diuraikan sebagai berikut:

1. Skor skala persepsi mahasiswa terhadap pembelajaran reflektif

Skor skala persepsi mahasiswa terhadap pembelajaran reflektif yang diterapkan di psikologi unhas dapat dilihat pada tabel dibawah ini:

Tabel 1 Skor skala persepsi mahasiswa terhadap pembelajaran reflektif.

\begin{tabular}{lcc}
\hline \multirow{2}{*}{ Kriteria } & \multicolumn{2}{c}{$\begin{array}{c}\text { Persepsi mahasiswa } \\
\text { terhadap pembelajaran } \\
\text { reflektif }\end{array}$} \\
\cline { 2 - 3 } & Jumlah & Presentasi \\
\hline $\begin{array}{l}2.00-2.99 \\
\text { (kurang } \\
\text { efektif) }\end{array}$ & 1 & $0.97 \%$ \\
\hline $\begin{array}{l}3.00-3.99 \\
\text { (efektif) }\end{array}$ & 81 & $78.65 \%$ \\
\hline $\begin{array}{l}4.00-4.99 \\
\text { (sangat } \\
\text { efektif) }\end{array}$ & 21 & $20.39 \%$ \\
\hline \multicolumn{2}{c}{ Total } \\
\hline
\end{tabular}




\section{Hasil Belajar (IPK) mahasiswa Program Studi Psikologi}

Berikut adalah rata-rata hasil belajar (IPK) mahasiswa program studi psikologi selama beberapa semester yaitu sebagai berikut:

Tabel 2. Hasil Belajar (IPK) mahasiswa Program Studi Psikologi

\begin{tabular}{cccc}
\hline \multirow{2}{*}{ IPK } & \multicolumn{3}{c}{ Nilai } \\
\cline { 2 - 4 } & Jumlah & Presentasi & \\
\hline $0.0-2.50$ & 1 & $0.97 \%$ & \\
\hline $2.51-2.99$ & 6 & $5.82 \%$ & \\
\hline $3.00-3.50$ & 47 & $45.63 \%$ & \\
\hline $3.51-4.00$ & 49 & $47.57 \%$ & \\
\hline IPK & & & 3.97 \\
Tertinggi & & & \\
\hline IPK & & & 1.65 \\
Terendah & & & 3.43 \\
\hline $\begin{array}{c}\text { Rata-Rata } \\
\text { IPK }\end{array}$ & & & \\
\hline
\end{tabular}

3. Hubungan persepsi mahasiswa terhadap pembelajar reflektif dengan hasil belajar

Data yang didapatkan pada penelitian ini diperoleh menggunakan skala persepsi mahasiswa terhadap pembelajaran reflektif yang disebarkan dalam bentuk skala likert pada mahasiswa Program Studi Psikologi Fakultas Kedokteran UNHAS yang berjumlah 103 orang yang terdiri dari 50 angkatan 2012 dan 53 angkatan 2013, di peroleh nilai skala persepsi terhadap pembelajaran reflektif pada masing-masing mahaswa dan disertai dengan IPK pada masing-masing mahasiswa (data tersebut dapat dilihat pada lampiran).
Selanjutnya, dari hasil yang diperoleh melalui skala yang berjumlah 30 item, kemudian data yang diperoleh tersebut diolah menggunakan bantuan SPSS versi 21 dan diolah menggunkan korelasi product moment. Berikut adalah hasil uji korelasi persepsi mahasiswa terhadap metode pembelajaran reflektif dengan hasil belajar (IPK) pada mahasiswa Program Studi Psikologi UNHAS sebagai berikut:

Tabel 3. Correlations

\begin{tabular}{|c|c|c|c|}
\hline & & $\begin{array}{l}\text { Hasil } \\
\text { Skala }\end{array}$ & IPK \\
\hline Hasil & Pearson & 1 & $.254^{* *}$ \\
\hline \multirow[t]{3}{*}{ Skala } & Correlation & & \\
\hline & Sig. (2-tailed) & & .010 \\
\hline & $\mathrm{N}$ & 103 & 103 \\
\hline \multirow[t]{3}{*}{ IPKS } & $\begin{array}{l}\text { Pearson } \\
\text { Correlation }\end{array}$ & $.254^{* * *}$ & 1 \\
\hline & Sig. (2-tailed & .010 & \\
\hline & $\mathrm{N}$ & 103 & 103 \\
\hline
\end{tabular}

Berdasarkan tabel tersebut terlihat bahwa nilai signifikansi antara persepsi mahasiswa terhadap pembelajaran reflektif $(\mathrm{X})$ terhadap hasil belajar $=$ index prestasi kumulatif $(\mathrm{Y})$ bernilai 0.010 yang berarti nilai tersebut lebih kecil dari $(<) 0.05$ atau $0.10<0.05$ yang berarti ada hubungan positif antara persepsi mahasiswa terhadap pembelajaran reflektif dengan hasi belajar (IPK) mahasiswa pada program studi psikologi fakultas kedokteran Universitas Hasanuddin.

Berdasarkan interpretasi kekuatan hubungan yang diungkapkan oleh Sarwono (2006), 
peneliti kemudian meninjau nilai Pearson Correlation pada tabel tersebut menunjukkan derajat hubungan antara kedua variable, nilai yang tercantum di dalam tabel adalah 0.254 yang menunjukkan bahwa korelasi antara keduanya cukup kuat. Dengan demikian, hipotesis dalam penelitian yaitu ada hubungan antara persepsi mahasiswa terhadap pembelajaran reflektif dengan hasi belajar (IPK) mahasiswa pada program studi psikologi fakultas kedokteran UNHAS diterima. Semakin baik persepsi terhadap pembelajaran reflektif maka akan semakin baik hasil belajar yang diperoleh oleh mahasiswa.

\section{Pembahasan}

Penelitian ini menggunakan skala persepsi mahasiswa terhadap metode pembelajaran reflektif untuk mengukur persepsi mahasiswa Psikologi Fakultas Kdeokteran UNHAS angkatan tahun 2012 dan 2013. Skala persepsi mahasiswa terhadap pembelajara reflektif yang awalnya dibuat oleh peneliti sejumlah 57 item di uji cobakan di angkatan 2014, setelah melewati tahapan analisis item terdapat 27 item yang gugur sehingga hanya terdapat 30 item yang di ujikan pada angkatan 2012 dan 2013.

Dari pemberian skala kepada 103 mahasiswa psikologi Fakultas Kedokteran UNHAS, diperolah data bahwa sebagian besar mahasiswa Program Studi Psikologi Fakultas Kedokteran UNHAS mempersepsikan bahwa metode pembelajaran reflektif yang diterapkan adalah efektif hingga sangat efektif. Dengan rincian yaitu, sebanyak $0.97 \%$ atau sekitar satu mahasiswa mempersepsikan bahwa metode pembelajran reflektif yang diterapkan di Program Studi Psikologi UNHAS adalah kurang efektif. Sebanyak $78.05 \%$ atau sekitar 81 mahasiswa mempersepsikan bahwa metode pembelajaran reflektif yang diterapkan adalah efektif. Dan sebanyak $20.39 \%$ atau sekitar 21 mahasiswa mempersepsikan bahwa metode pembelajaran reflektif yang diterapkan adalah sangat efektif.

Selain itu, diperoleh data mengenai hasil belajar yang ditinjau dari Indeks Prestasi Kumulatif (IPK), sebagian besar mahasiswa Program Studi Psikologi Fakultas Kedokteran UNHAS memperoleh IPK $>3.00$ dengan rincian yaitu, $0.97 \%$ atau satu mahasiswa memiliki IPK $>2.51,5.82 \%$ atau enam mahasiswa memperoleh $2.50<$ IPK < $3.01, \quad 45.03 \%$ atau 47 mahasiswa memperoleh $2.99<\mathrm{IPK}<3.51$, dan $47.57 \%$ atau 49 mahasiswa memperoleh $3.50<$ IPK $<4.00$.

Persepsi mahasiswa terhadap pembelajaran refleksitf berkorelasi positif dan signifikan dengan hasil belajar mahasiswa program 
Studi Psikologi Universitas Hasanuddin yang ditunjukkan oleh Indeks Prestasi Kumulatif (IPK). Hasil uji korelasi menggunakan korelasi product moment menunjukkan bahwa terdapat hubungan positif antara persepsi mahasiswa terhadap pembelajaran reflektif dengan Indeks Prestasi Kumulatif dimana nilai signifikansinya adalah 0.010 atau lebih kecil dari 0.05 sehingga hipotesis yang diajukan oleh peneliti diterima. Hubungan diantara kedua variable termasuk dalam kategori cukup kuat dengan koefisien korelasi sebesar 0.254. Korelasi positif dan signifikan antara persepsi mahasiswa terhadap pembelajaran reflektif memberikan arti bahwa jika mahasiswa mempersepsikan metode pembelajaran reflektif efektif diterapkan maka hasil belajar (IPK) juga akan baik.

Data penelitian menunjukkan bahwa mahasiswa Program Studi Psikologi UNHAS yang mempersepsikan pembelajaran reflektif itu efektif atau sangat efektif memperoleh IPK yang sebagian besar lebih besar atau sama dengan 3,00. Sebaliknya, yang mempersepsikan metode pembelajaran reflektif itu tidak efektif memperoleh IPK lebih kecil dari 3,00. Hal ini membuktikan bahwa persepsi mahasiswa terhadap metode pembelajaran reflektif berhubungan dengan pencapaian prestasi belajar seseorang. Adanya korelasi antara persepsi mahasiswa terhadap pembelajaran reflektif didukung oleh penelitian Purba (2013) yang menunjukkan hasil bahwa ada pengaruh positif pemberian model pembelajaran reflektif yang diberikan kepada siswa kelas VIII SMP Swasta Masehi Berastagi Tahun Pembelajaran 2013/2014. Nilai rata-rata siswa yang diberikan perlakuan (menggunakan model pembelajaran reflektif) lebih tinggi dibandingkan dengan sebelum mendapat perlakukan (tanpa menggunakan model pembelajaran reflektif).

Krech (Sudaryanto \& Irdawati, 2008) mengatakan bahwa proses kognitif yang mengawali terjadinya persepsi seseorang dipengaruhi oleh faktor internal (pribadi) dan faktor eksternal pengalaman, pengetahuan, proses belajar, wawasan pemikiran, keinginan, motivasi, dan tujuan. Sedangkan faktor eksternalnya meliputi lingkungan keluarga, fisik dan sosial budaya dimana orang bertempat. Dalam hal ini, ketika ditinjau menggunakan teori konstruksivisme dari John Dewey (Santrock, 2004) mengungkapkan bahwa salah satu hal yang berpengaruh dalam hasil belajr seseorang itu adalah dari pengalamannya, bagaimana seseorang masuk kedalam sebuah pengalaman, merasakan pengalaman tersebut dan merefleksikannya. Begitu juga, hal ini didukung oleh David A Kolb (Nasution, 
2009) yang mengungkapkan mengenai experiential learning, ketika seseorang merefleksikan apa yang ia dapatkan maka pengalaman dan pengetahuannya dapat bertambah karena seorang individu melalui pengalamannya dan lain-lain menyempurnakan pengetahuan yang telah ada sebelumnya pada seseorang tersebut ketika seseorang merefleksikan pengetahuan dan perasaan-perasaan yang ia dapatkan dalam proses pembelajaran melalui pengalamannya. Hal yang diungkapkan oleh John Dewey dan Kolb (Nasution, 2009) terbukti melalui penelitian ini bahwa hasil belajar yang didapatkan mahasiswa dapat menjadi positif, seiring dengan persepsi mahasiswa tentang merode pembelajaran reflektif yang diterapkan.

Salah satau faktor pendukung penelitian ini yaitu metode pembelajaran reflektif telah diterapkan di Program Studi Psikologi Fakultas Kedokteran UNHAS dan telah berlangsung selama tiga tahun belakangan ini serta index prestasi kumulatif (IPK) mahasiswa yang rata-rata diatas 3 sehingga mahasiswa angkatan 2012 dan 2013 telah merasakan manfaat dari me-refleksi-kan apa yang mereka dapatkan dalam proses pembelajaran mereka selama ini.

\section{SIMPULAN DAN SARAN}

\section{Simpulan}

Berdasarkan hasil penelitian mengenai hubungan persepsi mahasiswa terhadap pembelajaran reflektif dengan hasil belajar pada mahasiswa Psikologi Fakultas Kedokteran UNHAS, diperoleh hasil uji korelasi product moment yang menunjukkan nilai signifikansi sebesar 0.010 yang berarti lebih kecil $(<)$ dari 0.05 , hal tersebut menunjukkan hipotesis peneliti diterima dan terdapat hubungan positif persepsi mahasiswa terhadap pembelajaran reflektif dengan hasil belajar pada mahasiswa Psikologi Fakultas Kedokteran UNHAS. Hal ini berarti ketika mahasiswa mempersepsikan metode pembelajaran reflektif efektif diterapkan maka hasil belajar (IPK)-nya akan baik. Nilai korelasi diantara keduan variabel menunjukkan angka 0.254 yang berarti cukup kuat.

\section{Saran}

Berdasarkan hasil penelitian, maka peneliti dapat menyampaikan saran sebagai berikut:

1. Bagi tingkat sekolah ataupun perguruan tinggi, hendaknya pembelajaran reflektif dapat diterapkan pada proses pembelajaran sehingga siswa/mahasiswa dapat lebih berperan aktif dalam proses pembelajaran yang di ikuti olehnya.

2. Bagi peneliti berikutnya, hendaknya memerhatikan berbagai faktor lain 
yang dapat berpengaruh terhadap hasil belajar yang diperoleh oleh seseorang.

\section{DAFTAR RUJUKAN}

Azwar, S. (2011). Reabilitas dan Validitas. Yogyakarta: Pustaka Pelajar.

Coughlan, A. (2007). Reflective learning: Keeping a Reflective Learning Journal. London: DCU.

Mudayati, H. (2008). Hubungan Persepsi Mahasiswa Tentang Metode Pembelajaran dan Penguasaan Materi Dosendengan Prestasi Belajar Mahasiswa Prodi DIII Kebidanan Universitas Tulungagung. Tesis Magister Kedokteran Keluarga Universitas Sebelas Maret Surakarta.

Nasution, S. (2009). Sosiologi Pendidikan. Jakarta: Bumi Aksara.

Purba, R.E. (2013). Pengaruh Model Reflektif Terhadap Kemampuan Menulis Puisi Pada Siswa Kelas Viii SMP Swasta Masehi Berastagi Tahun Pelajaran 2013/2014. Jurnal Pendidikan, Medan.

Santrock, J.W. (2004). Psikologi Pendidikan Edisi ke-2. Jakarta: Prenada Media Group.

Sarwono, J. (2006). Metode Penelitian Kuantitatif dan Kualitatif. Yogyakarta: Graha Ilmu

Slameto. (2010). Belajar dan Faktor-Faktor Yang Mempengaruhi. Jakarta: PT.Rineka.

Sudaryanto, A., \& Irdawati. (2008). Persepsi Lansia Terhadap Kegiatan Pembinaan Kesehatan Lansia di Posyandu Wilayah Kerja Puskesmas Prambanan 1 Yogyakarta. Jurnal Kesehatan ISSN 1979-7621, vol. 1, No. 1, Juni $2008 \mathrm{Hal}$ 81-90.

Suharnan. (2005). Psikologi Kognitif. Surabaya: Srikandi
Sukmadinata, N. S. (2007). Metode Penelitian Pendidikan. Bandung: Remaja Roesdakarya.

Winkel, W.S. (2007). Psikologi Pengajaran. Jakarta: Gramedia. 